\title{
RASGRP1/APTX Ratio Equal or Greater than 5
}

National Cancer Institute

\section{Source}

National Cancer Institute. RASGRP1/APTX Ratio Equal or Greater than 5. NCI Thesaurus.

Code C97180.

An assay finding indicating that the ratio of the gene pair RASGRP1/APTX that is expressed in leukemic cells is equal to or greater than five. 